\title{
Genetic diversity analysis of Rose varieties from Grandiflora group based on ISSR molecular markers
}

\author{
Sophia S. Yudanova ${ }^{1, *}$, Svetlana A. Plugatar ${ }^{2}$, Zinaida K. Klimenko ${ }^{2}$,Vera K. Zykova ${ }^{2}$, \\ Olena L. Rubtsova ${ }^{3}$, and Olga Yu. Vasilyeva ${ }^{1}$ \\ ${ }^{1}$ Central Siberian Botanical Garden, SB RAS, 630090 Novosibirsk, Russia \\ ${ }^{2}$ Nikitsky Botanical Garden, National Scientific Center of the Russian Academy of Sciences, 298648 \\ Yalta, Russia \\ ${ }^{3}$ M.M. Gryshko National botanical garden National Academy of Sciences of Ukraine, 01014 Kiev, \\ Ukraine
}

\begin{abstract}
Kinship and genetic diversity determination among six rose varieties from the Grandiflora group were carried out using ISSR thechnics. The studied varities were divided into 3 clades: I) 'Lezginka', 'Queen Elizabeth' and 'Koralovy surpriz' varieties; II) 'Gurzuf' and 'Love' varieties; III) 'Komsomolsky ogonek' variety formed a separate branch. This division into clades was confirmed by a statistical comparison of morphometric characters. On the basis of the obtained data, it can be concluded that the analysis using the selected primer group is well-suited for differentiation rose varieties into groups, which makes it possible, for one thing, to determine the genetic distance between varieties, and for another, to use these data in the future by certification of the varieties promising by resistance characters to the continental climate conditions.
\end{abstract}

\section{Introduction}

Rose is the most popular and widely cultivated crop in the world ornamental gardening. It is an ornamental crop including different species, interspecific hybrids in genus Rosa L. The classification of roses approved by the World Federation of Rose Society (WFRS) for garden groups is not always corelated with the botanical classification. Modern classification of garden roses is based in most cases not on the origin, but on ornamental and morphological characters.

Grandiflora is a rose group created in the middle of the 20th century by back crossing of hybrid tea forms and floribundas. Obtained hybrids did not match any of the groups that existed at that time. 'Queen Elizabeth' was the first representative of the Grandiflora group and still remains the standard for new cultivars of this group. This cultivar is widely known and popular all over the world due to its decorative value, resistance to diseases and adverse conditions, which in turn has led to the repeated using of 'Queen Elisabeth' as parental form when breeding new varieties. Grandiflora roses have large goblet flowers of a hybrid

\footnotetext{
*Corresponding author: judanowa.sophia@yandex.ru
} 
tea type. They are superior to medium-sized floribunda cultivars in bush height, but inferior in the flowers number in the inflorescence.

Genetic diversity estimation was carried out by ISSR-PCR technique. Inter simple sequence repeat, ISSR marker technique was developed by E. Zietkiewicz [1]. This technique based on the amplification of regions between DNA adjacent microsatellite sequences via polymerase chain reaction (PCR). ISSR markers are well suited to genetic diversity studies, phylogeny, gene tagging, genome mapping, and evolutionary biology due to the high polymorphism [2-5].

The goal of the present investigation was to estimate the level of relationships and the genetic diversity among six rose varieties from the Grandiflora group.

\section{Material}

The study was carried out on the base of the bioresource scientific collection "Collections of living plants in outdoor and indoor", UNU No. USU 44053 (Central Siberian Botanical Garden, SB RAS). Six rose varieties belonging to the grandiflora group were used as a material for investigation:

- 'Gurzuf' - has deep pink buds, cup-shaped, with a strong fragrance, pink flowers with creamy touches and a creamy reverse side; flowers arranged singly or in inflorescences up to $4 \mathrm{FL}$; leaves are dark green, glossy.

- 'Lezginka' - has dark red buds, goblet-shaped, fragrant, bright red flowers with a yellow eye; flowers arranged singly or in inflorescences up to $5 \mathrm{FL}$; leaves are dark green with a bronze tint.

- 'Koralovy surpriz' - has scarlet buds, goblet-shaped, fruity fragrant, coral pink flowers; flowers arranged singly or in inflorescences up to 5 FL; leaves are dark green, leathery.

- 'Queen Elizabeth' - has fragrant pink flowers with a high center, flowers arranged singly or in inflorescences up to 6 FL; leaves are dark green, leathery.

- 'Komsomolsky ogonek' - has red-orange buds, cupp-shaped, weak fragrant, blood-red flowers - bright and velvety, with a white-yellow eye, flowers arranged singly or in inflorescences up to $5 \mathrm{FL}$; leaves are dark green, glossy.

- 'Love' - has red buds, goblet-shaped, weak fragrant, bright red flowers with a silvery-white reverse side of petals, flowers arranged mainly singly; leaves are dark green, leathery.

\section{Methods}

DNA isolation from dried leaves was carried out using CTAB procedure with some modifications [6]. The CTAB buffer included CTAB, sodium chloride $(\mathrm{NaCl})$, and ethylenediaminetetraacetic acid (EDTA) Tris2-amino-2-hydroxymethyl-1,3-propanediol (TRIS) and $\beta$ mercaptoethanol. Crude DNA samples were purified twice with an equal volume of chloroform : isoamyl alcohol (24:1) and precipitated by using isopropanol.

The study used 6 six primers characterized by a clear, reproducible, polymorphic pattern: 17899B, HB-12, M-2, UBC 807, UBC 855, UBC 834 (table 1). Polymerase chain reaction (PCR) was performed on $\mathrm{C}-1000$ thermocycler (BioRad, USA). PCR reactions were carried out in $25 \mu \mathrm{L}$ volume reaction mixture containing $2 \mu \mathrm{L}$ of genomic DNA template, $2.5 \mu \mathrm{L} 10 \mathrm{X}$ Taq buffer without Mg2+, $1 \mu \mathrm{M}$ dNTPs, $2.3 \mu \mathrm{M} \mathrm{MgCl} 2,2 \mu \mathrm{L}$ primer, $0,2 \mu \mathrm{L}$ Taq polymerase $(5 \mathrm{u} / \mu \mathrm{l})$ and $15 \mu \mathrm{L}$ purified water $\left(\mathrm{ddH}_{2} \mathrm{O}\right)$. The PCR amplification conditions were: initial extended step of DNA denaturation at $95^{\circ} \mathrm{C}$ for $2 \mathrm{~min}$, followed by 38 cycles of denaturation at $94^{\circ} \mathrm{C}$ for $20 \mathrm{sec}$, primer annealing for $30 \mathrm{sec}$ (annealing temperatures and nucleotide sequences are shown in Tab. 1), elongation -1.5 
min and final elongation - 7 min. Reaction products were mixed with $2 \mu \mathrm{L}$ Sybr Green I, an intercalating dye specific for double-stranded DNA.

Electrophoretic separation of amplification products was done in a 1-1.5\% agarose gel with 1x TBE-buffer. Electrophoresis was done at $80 \mathrm{~V}$ for about $2 \mathrm{~h}$. The polymorphism quantitative estimation of applied markers and divergence level determination between the studied simples was based on the state matrices of binary characters. The presence or absence of the target sequence of a certain fragment length, i.e. the same size PCR fragment was designated as states 1 or 0 .

Statistical evaluation of obtained data was carried out using software package TreeCon (version 1.3b) [7]. Genetic distances were calculated by the formula:

$$
\mathrm{GD} x y=1-2 \mathrm{Nxy} /(\mathrm{N} x+\mathrm{N} y)
$$

where $\mathrm{Nxy}-$ is a common fragments number for $\mathrm{x}$ and y samples, $\mathrm{Nx}$ and $\mathrm{Ny}-$ are numbers of fragments for $\mathrm{x}$ and $\mathrm{y}$ samples respectively [8].

Dendrograms were created using the Neighbor-Joining (NJ) algorithm with 100 bootstrap pseudo-replicas. The polymorphism percentage $(\mathrm{P}, \%)$ of each primer was calculated with the formula:

$$
\mathrm{P}=100 \times \mathrm{Np} / \mathrm{N}
$$

where $\mathrm{Np}-$ is a polymorphic fragment number, $\mathrm{N}-$ is a total fragment number.

To determine a significant difference between morphometric characters of studied varieties Student's t-test was used [9]. T-value was calculated with the formula:

$$
t=\longdiv { m _ { 1 } ^ { 2 } + m _ { 2 } ^ { 2 } }
$$

where $\mathrm{M}$ - an average mean and $\mathrm{m}$ - a standard error.

\section{Results and discution}

Microsatellite DNA regions of the studied samples were analyzed using 6 ISSR primers (Tab. 1). Each amplified fragment (DNA band) was defined as an independent character, being designated as present -1 or absent -0 , resulting a binary data matrix which was used to compute primer banding characteristics such as: total number of bands, number of polymorphic bands, percentage of polymorphic bands.

122 amplified fragments (bands) from 250 to $3000 \mathrm{bp}$ in length were identified, from which 109 were polymorphic. The number of fragments amplified by a primer range from 18 (HB12 and UBC834) to 23 (17899B) (Tab. 1).

The polymorphism level detected by a single primer varied from 77.8 (amplified with HB-12) to $94.4 \%$ (with UBC-857), and averaged is $91.42 \%$. An ISSR profile of the samples obtained by amplification with HB12 primer is presented on the figure 1.

Table 1. Characteristics of the ISSR primers used for the detection of genetic polymorphism in 6 rose varieties from grandiflora rose group.

\begin{tabular}{|c|c|c|c|c|c|c|}
\hline Primer & Sequence, 5'-3' & $\begin{array}{c}\text { Annealing } \\
\text { temp., } \mathbf{C}^{\circ}\end{array}$ & TNB$^{*}$ & NBP* $^{*}$ & $\begin{array}{c}\text { PPB*, } \\
\text { \% }\end{array}$ & $\begin{array}{c}\text { Size range of } \\
\text { fragments, bp }\end{array}$ \\
\hline HB 12 & $(\mathrm{CAC})_{3} \mathrm{GC}$ & $42^{\circ} \mathrm{C}$ & 18 & 14 & 77,8 & $500-2400$ \\
\hline $\mathbf{1 7 8 9 9} \mathbf{B}$ & $(\mathrm{CA})_{6} \mathrm{GG}$ & $42^{\circ} \mathrm{C}$ & 23 & 21 & 91,3 & $250-2800$ \\
\hline UBC 807 & $(\mathrm{AG})_{8} \mathrm{~T}$ & $52^{\circ} \mathrm{C}$ & 21 & 19 & 90,5 & $500-2500$ \\
\hline UBC 834 & $(\mathrm{AG})_{8} \mathrm{YT}$ & $60^{\circ} \mathrm{C}$ & 18 & 17 & 94,4 & $300-2000$ \\
\hline UBC 855 & $(\mathrm{AC})_{8} \mathrm{YT}$ & $50^{\circ} \mathrm{C}$ & 22 & 20 & 90,9 & $700-2000$ \\
\hline $\mathbf{M 2}$ & $(\mathrm{AC})_{8} \mathrm{YG}$ & $50^{\circ} \mathrm{C}$ & 20 & 18 & 90,0 & $300-2500$ \\
\hline
\end{tabular}


* TNB - total number of bands, NPB - number of polymorphic bands, PPB - percentage of polymorphic bands.

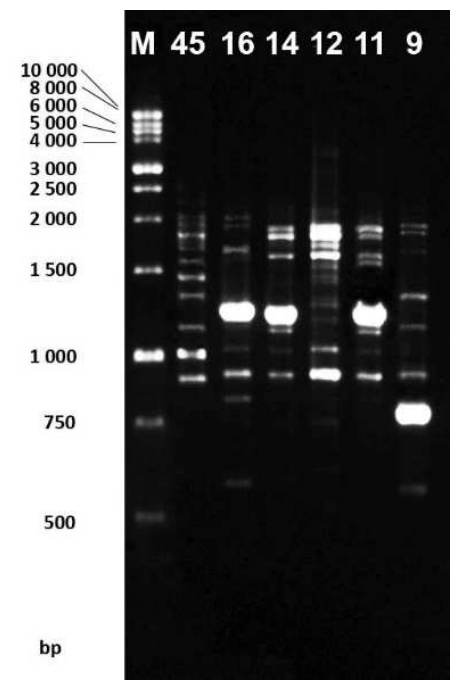

Fig. 1. Electrophoregram of PCR products obtained by DNA amplification with ISSR primer H12 $(\mathrm{CAC})_{3}$ GC. Track M - DNA marker, tracks with designation of samples: 9 - 'Gursuf', 11 - 'Lezginka', 12 - 'Koralovy surpriz', 14 - 'Queen Elizabeth', 16 - 'Komsomolsky ogonek', 45 - 'Love'

On the basis of the obtained dendrogram (Fig. 2), the studied samples were divided into 3 clusters. The first cluster (I) included the 'Lezginka', 'Queen Elizabeth' and 'Koralovy surpriz' varieties, the second - the 'Gurzuf' and 'Love' varieties (II). 'Komsomolsky ogonek' variety was the farthest from other samples and formed a separate branch (III). The 'Queen Elizabeth' variety was used more likely as a parent form by 'Lezginka' variety breeding, as evidenced by the genetic distance (0.1) with a high level of statistical support ${ }^{1}$ (>90).

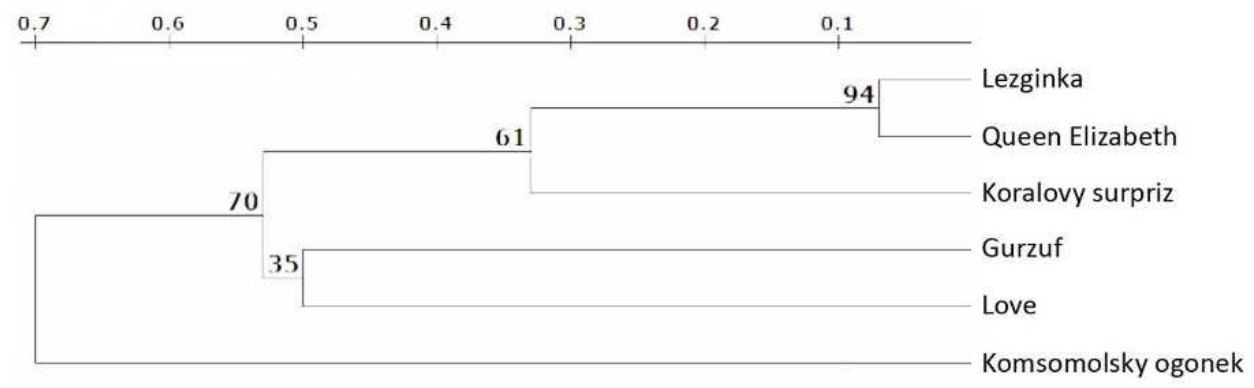

Fig. 2. Dendrogram built with the Neighbor-Joining algorithm based on ISSR-PCR spectra data of studied rose varieties. Node numbers indicate the level of statistical branch bootstrap.

Morphometric character data of studied varieties are presented in Table 2: flower diameter, petal number, peduncle length, bush height. Statistical comparison of morphometric characters using Student's t-test confirms the division of the studied varieties into 3 clade. Comparison of the 'Komsomolskiy Ogonek' variety that distinguished as the third separate clade with varieties from the first clade showed a statistically significant

\footnotetext{
${ }^{1}$ bootstrap proportions $>70$ considered as high reliable (with greater than or equal to $95 \%$ probability).
} 
difference (T criterion, P> 0.95) in all characters with the 'Queen Elizabeth' and 'Lezginka' varieties, as well as in three characters with the 'Koralovy surpriz' variety (flower diameter, petal number and bush height). Comparison of the 'Komsomolsky Ogonek' variety with the 'Gurzuf' and 'Love' varieties from the second clade showed a statistically significant difference (T criterion, $\mathrm{P}>0.95$ ) in two characters (flower diameter, number of petals).

Table 2. Morphometric characteristr of studied rose varieties from grandiflora group.

\begin{tabular}{|l|c|c|c|c|c|}
\hline \multicolumn{1}{|c|}{ Variety } & N & $\begin{array}{c}\text { Flower } \\
\text { diameter, cm }\end{array}$ & $\begin{array}{c}\text { Petals } \\
\text { number }\end{array}$ & $\begin{array}{c}\text { Peduncle } \\
\text { length, cm }\end{array}$ & $\begin{array}{c}\text { Bush } \\
\text { height, cm }\end{array}$ \\
\hline Queen Elizabeth & 20 & $8,75 \pm 0,22$ & $29,92 \pm 0,71$ & $41,33 \pm 2,20$ & $63,67 \pm 1,36$ \\
\hline Komsomolsky ogonek & 20 & $7,92 \pm 0,14$ & $21,25 \pm 0,64$ & $50,17 \pm 1,91$ & $73,25 \pm 2,68$ \\
\hline Koralovy surpriz & 20 & $9,27 \pm 0.18$ & $24.75 \pm 0.81$ & $45,25 \pm 2,37$ & $65,95 \pm 1,33$ \\
\hline Gurzuf & 20 & $10,24 \pm 0,19$ & $35,65 \pm 0,91$ & $51,95 \pm 1,71$ & $78,15 \pm 1,80$ \\
\hline Lezginka & 20 & $8,97 \pm 0,23$ & $25,20 \pm 0,79$ & $68,45 \pm 1,62$ & $85,50 \pm 1,44$ \\
\hline Love & 20 & $9,42 \pm 0,20$ & $32,85 \pm 0,84$ & $53,50 \pm 1,38$ & $70,20 \pm 1,92$ \\
\hline
\end{tabular}

On the basis of the obtained data, it can be concluded that the analysis using the selected primer group is well-suited for differentiation rose varieties into groups, which makes it possible, firstly, to determine the genetic distance between varieties, and secondly, to use these data in the future when certifying of the varieties that are promising in terms of complex resistance to the conditions of the continental climate.

Acknowledgements. The work was carried out with financial support from the budgetary project of Central Siberian Botanical Garden, SB RAS "Analysis of biodiversity, conservation and restoration of rare and resource plant species using experimental methods. (No.AAAA-A21-121011290025-2) within the framework of the State Assignment and with material of CSBG representing USU (Unique Scientific Unit) "Collections of living plants indoors and outdoors".

\section{Reference}

1. E. Zietkiewicz, A. Rafalski, D. Labuda, Genomics, 20 (1994)

2. T. Amom, P. Nongdam, Int. J. Cur. Res. Rev., 9, 1 (2017)

3. G. Duta-Cornescu, C.-E. Pavlusenco, D. M. Pojoga, M. E. Negulici, N. Constantin, A. Simon-Gruita, AgroLife Sci. J., 6(1) (2017)

4. A. Patwardhan, S. Ray, A. Roy, J. Phylogen, Evolution. Biol., 2(2) (2014)

5. A.S. Saqer, H.M. Mohamed, G. Ahmed, A.S. Bandar, Res. J. Biothechnol. 14(6) (2019)

6. J. Heikrujam, R. Kishor, P.B. Mazumder, Biochemical Analysis Tools, Methods for Bio-Molecules Studies (Intech Open, 2020)

7. Y. Van de Peer, R. De Wachter, Comput. Appl. Biosci. 10 (1994)

8. M. Nei, W.-H. Li, Proc. Natl Acad. Sci. USA, 76 (1979)

9. R. R. Sokal, F. J. Rohlf, Biometry the principles and practice of statistics in biological research (Freeman \& company, NY, 2011) 